\title{
Recurrence risks in mental retardation
}

\author{
Yanick J Crow, J L Tolmie
}

\begin{abstract}
Despite improvements in diagnostic techniques and progress made in mapping genes associated with syndromal mental handicap, the estimation of recurrence risks in non-syndromal mental retardation is still dependent on empirical data. Unfortunately, few studies are available to guide the clinician and their results differ significantly. For example, recurrence risks to all sibs of a male index patient with severe mental retardation vary between $3.5 \%$ and $14 \%$ in commonly quoted series. The present review highlights the problems involved in interpreting the previous work in this area and discusses the definition of mental retardation according to the degree of severity, phenotype, and its pattern of inheritance. In planning future studies, an appreciation of these issues should allow us to derive accurate and comparable risk figures for use in counselling affected subjects and their families.
\end{abstract}

(F Med Genet 1998;35:177-182)

Keywords: mental retardation; recurrence risks

The diagnosis of mental retardation in a child comes as a tremendous blow for most affected families and the assessment of such children and young adults represents a major part of the work load of a clinical genetics department. In a minority of cases where a cause is apparent, or there is an obvious pattern of inheritance, counselling with respect to the risk of recurrence is straightforward. However, in most cases no cause is identified and in this situation the clinical geneticist is forced to rely on empirical risk figures for guidance. Since Penrose's original survey of mental retardation in $1938,{ }^{1}$ a number of studies of recurrence risks in mental retardation have been performed but the methods used vary and their results differ significantly. Moreover, recent advances in the investigation of patients with mental retardation (in particular, detailed cytogenetic analysis, neuroimaging, and a molecular test for the fragile $\mathrm{X}$ syndrome) diminish the applicability of older studies for present day counselling purposes. Here, we review the available published reports on mental retardation recurrence risks, highlight areas of uncertainty, and consider the implications for genetic counselling.

\section{Defining mental retardation}

Although definitions of mental retardation often vary between series, ${ }^{2}$ classification on the basis of intelligence quotients (IQ) has been commonly used. Assuming that $\mathrm{IQ}$ is a normally distributed continuous variable with a population mean of 100 and standard deviation of 15 , mental retardation may be classified within approximate IQ ranges as "mild", within the range 50 to $70(-2.0$ to $-3.3 \mathrm{SD})$, or "severe" when IQ is less than $50 .^{3}$ More recently, some psychologists have become reluctant to quote an IQ assessment, preferring reports profiling strengths and weaknesses in various skills. This is useful for management, but less so for genetic diagnosis and obviously makes the definition of degree of mental retardation difficult.

Attendance at schools for children with learning difficulties has also been used as an indicator of degree of mental retardation, but such a classification is not necessarily commensurate with the definitions according to IQ. For example, in a study based on placement at schools for children with mild mental retardation, only $53 \%$ of those included had an IQ in the range $50-70 .{ }^{4}$ In a similarly defined group studied by Bundey et $a l,{ }^{5} 27 \%$ had an IQ less than 50 or greater than 70 and in a study of children attending schools for those with severe mental retardation, Bundey $e t a t$ found $21 \%$ had an IQ above 50. Moreover, changing educational practice has made the definition of ability groups by institution, or even by criteria such as "special needs" provision, increasingly difficult.

\section{Prevalence}

A recent detailed review of mental retardation prevalence studies concluded that severe mental retardation has a prevalence of 3.8 per 1000 whereas the prevalence estimates for mild mental retardation vary so much that the true prevalence rate remains uncertain. ${ }^{7}$ Again, on the assumption that IQ is a normally distributed continuous variable, by definition $2.3 \%$ of children have mild mental retardation. ${ }^{8}$ Note that in most genetic studies, case ascertainment is problematic because as long as children with 
Table 1 Summary table of selected papers reporting recurrence risks for idiopathic mental retardation

\begin{tabular}{|c|c|c|c|}
\hline Reference & Cytogenetics & $\begin{array}{l}\text { Fragile } X \\
\text { assessment }\end{array}$ & Comments \\
\hline 34 & No & No & $\begin{array}{l}523 \text { males and } 401 \text { females seen at a hospital clinic } \\
\text { before } 1970 \text {. IQ assessment of mental retardation. } \\
\text { Note, in } 50 \% \text { of sibs the form of retardation was either } \\
\text { different from the index patient or unknown }\end{array}$ \\
\hline 27 & No & Clinical & $\begin{array}{l}179 \text { patients with severe mental retardation }(\mathrm{IQ}<50) \\
\text { derived from a hospital register. All families reviewed by } \\
\text { authors }\end{array}$ \\
\hline 35 & Variable & No & $\begin{array}{l}351 \text { patients defined by "severe psychomotor } \\
\text { retardation" or IQ<70. Hospital based series seen } \\
\text { between } 1972-76 . \text { Recurrence risks not analysed by } \\
\text { degree of mental retardation or by sex of proband. } \\
\text { Exclusion of cases with a male maternal first cousin } \\
\text { with mental retardation. Uncertainty about the } \\
\text { classification of cases by "Cranial contour } \\
\text { abnormalities". The recurrence risk in a group of } 45 \\
\text { index patients with non-specific mental retardation was } \\
19 \% \text { (table 2) }\end{array}$ \\
\hline 15 & Variable & No & $\begin{array}{l}1560 \text { patients with severe mental retardation seen at a } \\
\text { hospital clinic. } 40 \text { patients with "Pure severe mental } \\
\text { retardation". Clinical assessment of mental retardation. } \\
\text { Rigorous investigation/examination protocol. Specific } \\
\text { figures for severe mental retardation with multiple } \\
\text { congenital anomalies and severe mental retardation } \\
\text { with cerebral palsy }\end{array}$ \\
\hline 24 & Variable & Variable & $\begin{array}{l}\text { Population based registry. } 1952-1965 \text { cohort. } 2209 \\
\text { index cases not assessed directly by authors. IQ } \\
\text { assessment of mental retardation }\end{array}$ \\
\hline 6 & 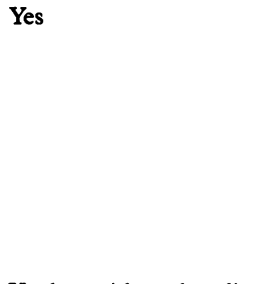 & Cytogenetic & $\begin{array}{l}156 \text { male index cases with severe mental retardation } \\
\text { identified from a school population. IQ assessment of } \\
\text { mental retardation. } 33 \text { children with IQ }>50 \text {. Note } 39 \\
\text { cases with a specific cause for mental retardation } \\
\text { included in "idiopathic" group. However, exclusion of } \\
\text { these cases does not significantly alter the recurrence } \\
\text { risks given (S Bundey, personal communication). } \\
\text { Exclusion of } 14 \text { boys identified with a cytogenetic } \\
\text { diagnosis of fragile X syndrome. Note the high } \\
\text { recurrence rate in this group (5/17 male sibs) }\end{array}$ \\
\hline 29 & Yes but without banding & No & $\begin{array}{l}302 \text { index cases seen at a hospital clinic. Mental } \\
\text { retardation assessed on the basis of IQ. Concern about } \\
\text { the criteria used for subclassification (in particular } \\
\text { "Biological background by medical history") }\end{array}$ \\
\hline 5 & Yes & Cytogenetic & $\begin{array}{l}228 \text { index cases with mild mental retardation defined } \\
\text { by attendance at an ESN school. IQ assessment of } \\
\text { mental retardation. } 61 \text { children with IQ }>70 \text { and } 40 \\
\text { children with IQ }<50.20 \text { children excluded because of a } \\
\text { cytogenetic diagnosis of fragile X syndrome. Asian } \\
\text { population studied separately }\end{array}$ \\
\hline
\end{tabular}

an IQ of less than 70 cope to some extent within the regular school system, they are usually excluded.

\section{Why distinguish mild and severe mental retardation?}

The idea that mild mental retardation represents one end of a spectrum of intelligence while severe mental retardation results from discrete events, genetic or otherwise, having a catastrophic effect on mental development, is well validated. ${ }^{9}$ Thus, people with severe mental retardation only rarely have a family history of mental retardation and their social class distribution approximates to that of the general population. ${ }^{10}$ In contrast, there is a much increased likelihood for mild mental retardation to be familial and affect people from socially disadvantaged backgrounds. ${ }^{11}$ Most importantly, a biomedical cause is identified twice as frequently in severe mental retardation (up to $50 \%$ of cases) compared with mild mental retardation (less than $20 \%$ ). ${ }^{12}$ However, that a substantial minority of people with mild mental retardation have an identifiable pathological cause for their handicap, and that people with the same identifiable cause can show differing severities of retardation, highlights the shortcomings in such a classification.
As discussed below, it may be that for the purposes of recurrence risk estimation the level of mental retardation is less important than the presence of a qualitative difference in intelligence between a child and his/her parents and sibs.

\section{Mental retardation phenotypes}

Two particular terms should be distinguished. Idiopathic mental retardation occurs where no cause is identified. It is a diagnosis of exclusion and certainly comprises a number of different conditions. The use of the term non-specific mental retardation should refer to a subgroup where patients have no distinguishing physical or neurological characteristics. There is debate about the proportion of cases in this group that have an $\mathrm{X}$ chromosome linked gene defect (see below). When examination or investigation shows abnormal characteristics, such as restricted growth (of the cranium/stature), specific dysmorphic features, a recognisable behavioural phenotype, congenital anomalies, neurological problems such as spasticity (symmetrical/asymmetrical), or a neuroimaging abnormality such as lissencephaly, the case description should include these features since better recurrence risk data might be available. ${ }^{13-18}$ Well defined autism carries a low 
Table 2 Sib recurrence risks for index patient (IP) with severe idiopathic mental retardation

\begin{tabular}{|c|c|c|c|c|c|c|c|}
\hline \multirow[b]{2}{*}{ Reference } & \multicolumn{3}{|l|}{ Male IP } & \multicolumn{3}{|l|}{ Female IP } & \multirow[b]{2}{*}{ Comments } \\
\hline & Brother & Sister & All sibs & Brother & Sister & All sibs & \\
\hline 34 & & & $2-9 \%$ * & & & $3.5-4 \%^{\star}$ & $\begin{array}{l}\text { Table } 1 \text { "Undiagnosed" column. Note, in } 50 \% \text { of sibs the } \\
\text { form of retardation was either different from the index } \\
\text { case or unknown. *Unable to combine groups with } \\
\text { IQ }<50\end{array}$ \\
\hline 27 & $5.2 \%(6.7 \%)$ & $1.6 \%(3.2 \%)$ & $3.5 \%(5 \%)$ & $2.2 \%(4.4 \%)$ & $2.1 \%(6.3 \%)$ & $2.2 \%(5.4 \%)$ & $\begin{array}{l}\text { Table 4. Figures for severe mental retardation in sibs. The } \\
\text { figures in brackets are for sibs with either mild or severe } \\
\text { mental retardation }\end{array}$ \\
\hline 15 & & & $14 \%$ * & & & $14 \%$ * & $\begin{array}{l}40 \text { cases of "Pure mental retardation" (ie, non-specific) } \\
\text { without autism. ^Recurrence risks not broken down by } \\
\text { sex of proband }\end{array}$ \\
\hline 24 & $6 \%$ & $2.3 \%$ & $4.3 \%$ & $2.9 \%$ & $5.6 \%$ & $4.2 \%$ & $\begin{array}{l}\text { Adjustment of table II by incorporation of } 1125 \text { cases } \\
\text { with IQ }<50 \text { into "severe" mental retardation. Note the } \\
\text { overall "Total" figures given in table II include } 588 \text { index } \\
\text { cases with unspecified level of mental retardation }\end{array}$ \\
\hline 6 & $10 \%$ & $5 \%$ & $7.5 \%$ & & & & $\begin{array}{l}\text { Table 7. Males only (boys with a cytogenetic diagnosis of } \\
\text { fragile } X \text { syndrome excluded). Only sibs with severe } \\
\text { mental retardation included. Note the high risk of mild } \\
\text { mental retardation in the sibs of these males ( } 7 \% \text { for all } \\
\text { sibs). If children with a cytogenetic diagnosis of fragile } X \\
\text { syndrome are included the recurrence risks are } 12 \% \text { and } \\
4 \% \text { for the brothers and sisters respectively }\end{array}$ \\
\hline 29 & $14 \%$ & $14 \%$ & $14 \%$ & $8.5 \%$ & $9.6 \%$ & $9.2 \%$ & $\begin{array}{l}\text { Derived from "Total" figures given in tables I-IV. } 181 \\
\text { cases with an } I Q<50\end{array}$ \\
\hline
\end{tabular}

recurrence risk (although the risk may be higher for other phenotypes within the "autistic spectrum"), ${ }^{19}$ but since about three quarters of autistic people have an IQ below 70, care should be taken to try and differentiate those with autism complicated by reduced intelligence from those with mental retardation showing some autistic features.

Inevitably, individual cases may be difficult to classify and, at present, clinicians make empirical judgements: for example, mental retardation in a young child with hypotonia and disequilibrium is possibly more likely to have a single gene aetiology than mental handicap with spasticity, reduced somatic growth, and epilepsy, although there is little published evidence addressing this assertion.

THE “CHROMOSOMAL" PHENOTYPE

Why a case is judged "chromosomal" is often difficult to define but clinicians suspect chromosome imbalance when there is mental handicap, reduced stature or head circumference, and dysmorphism that is mostly evident in the face, distal limbs, and (male) genitalia. Within particular populations, cytogenetic analysis (including the use of skin biopsy where the phenotype is suggestive of mosaicism) has detected chromosomal anomalies in up to $30 \%$ of cases with severe retardation ${ }^{6}$ and $10 \%$ of cases with mild mental retardation, ${ }^{4}$ but trisomy 21 is by far the most frequent abnormality and is readily diagnosed. Recently, however, there is much appreciation of the importance of submicroscopic or cryptic chromosome lesions, several megabases or less in size, that are undetectable by conventional cytogenetic analysis. Flint et $a l^{\circ}$ found three cryptic chromosome anomalies in a total of 99 cases of idiopathic mental retardation, including one child with non-specific mental retardation. These authors estimated that cryptic chromosome rearrangements in the telomeric regions (which have a high concentration of genes and are affected more commonly by chromosomal rearrangements than other parts of the genome) cause $6 \%$ or more of idiopathic mental retardation. Ledbetter ${ }^{21}$ has discussed in detail the clinical situations in which an underlying cryptic translocation should be considered.

It seems probable that severely affected subjects with dysmorphic features are more likely to have cryptic lesions and certain familial cases, especially where there are unaffected intervening relatives, are at high risk. ${ }^{39}$ However, in the absence of a whole genome screening test for cryptic chromosome imbalance, the true prevalence is uncertain and the proportions of unbalanced cryptic aberrations that are de novo or arise as a result of an inherited balanced rearrangement are also unknown. This point is important in the assessment of recurrence risks where the phenotype is judged "chromosomal" despite a normal karyotype.

\section{$X$ linked genes and non-specific mental retardation}

$X$ LINKED MENTAL RETARDATION

It has long been recognised that males consistently outnumber females in surveys of mental retardation and the possibility of $X$ linked mental retardation represents a major concern for genetic counsellors. ${ }^{22}$ Lehrke ${ }^{23}$ hypothesised that non-specific $X$ linked mental retardation could account for the excess of mentally retarded males in a population. Bundey et $a l^{b}$ observed in brothers of affected males with severe mental retardation a recurrence risk that was three times that for sisters (this figure includes subjects with a cytogenetic diagnosis of the fragile X syndrome). Herbst and Baird ${ }^{24}$ also found an increased recurrence risk for brothers of male cases with idiopathic severe mental retardation (IQ 20-35) and for the brothers of male cases with non-specific mental retardation (where no distinction was recorded for level of mental retardation). Herbst and Miller $^{25}$ calculated a frequency for non-specific $\mathrm{X}$ linked mental retardation of 1.83 per 1000 males and suggested that $27 \%$ of all nonspecific mental retardation in males might be 
Table 3 Sib recurrence risks for index patient (IP) with mild idiopathic mental retardation

\begin{tabular}{|c|c|c|c|c|c|c|c|}
\hline \multirow[b]{2}{*}{ Reference } & \multicolumn{3}{|l|}{ Male IP } & \multicolumn{3}{|c|}{ Female IP } & \multirow[b]{2}{*}{ Comments } \\
\hline & Brother & Sister & All sibs & Brother & Sister & All sibs & \\
\hline 34 & & & $8 \%$ & & & $4 \%$ & $\begin{array}{l}\text { Table } 1 \text { "Undiagnosed" column. "Mildly retarded" } \\
\text { (IQ } 52-67 \text { ). Note in } 50 \% \text { of sibs the form of } \\
\text { retardation was different from the index patient or in } \\
\text { doubt }\end{array}$ \\
\hline 24 & $4.6 \%$ & $2.9 \%$ & $3.7 \%$ & $1.8 \%$ & $3.1 \%$ & $2.4 \%$ & $\begin{array}{l}\text { Table III. Minimum estimates of recurrence risk in } \\
561 \text { index patients with IQ } 52-67\end{array}$ \\
\hline 29 & $20 \%$ & $17 \%$ & $19 \%$ & $30 \%$ & $21 \%$ & $26 \%$ & $\begin{array}{l}\text { Derived from "Total" figures given in tables I-IV. } \\
121 \text { index patients with IQ } 50-69\end{array}$ \\
\hline 5 & $20 \%$ & $16 \%$ & $17.8 \%$ & $25 \%$ & $14.5 \%$ & $19.8 \%$ & $\begin{array}{l}\text { Table } 4.10 \text { males and } 10 \text { females excluded with a } \\
\text { cytogenetic diagnosis of fragile X syndrome. Note } \\
\text { the low recurrence risk ( } 1.5 \% \text { excluding the } \\
\text { offspring of consanguineous marriages) for the } \\
\text { Asian group analysed }\end{array}$ \\
\hline
\end{tabular}

the result of an $\mathrm{X}$ linked defect. These figures were derived from the observation of an excess of 72 male-male affected sibships in a British Columbian birth cohort based on a number of assumptions which included that the excess of affected brother-brother pairs over affected sister-sister pairs were all examples of $X$ linked inheritance, zero fitness of affected males, and equal fitness of carrier and non-carrier females. Morton $e t a l^{26}$ suggested a similar figure.

Evidence for a significant $\mathrm{X}$ linked component to mental retardation has not been confirmed in all studies. Bundey and Carter ${ }^{27}$ noted an excess of males in a study of 179 children with idiopathic severe mental retardation. However, since no excess of retarded male sibs was observed, they rejected this sex difference as being the result of $X$ linked genes, attributing it to the greater susceptibility of males to environmental effects. In a population study from Coventry, Bundey et $a \dot{P}$ found no evidence of a contribution by $\mathrm{X}$ linked genes to idiopathic mild mental retardation. However, a number of these children, originally identified on the basis of a cytogenetic diagnosis of the fragile X syndrome, were incorrectly excluded from analysis. ${ }^{28}$ Costeff and Weller ${ }^{29}$ also found no increase of segregation ratio among male sibs of male probands with non-specific mental retardation although confidence limits for their data were wide.

\section{THE FRAGILE $X$ SYNDROME}

The recognition of the fragile $\mathrm{X}$ syndrome was felt initially to confirm Lehrke's observations on the importance of $\mathrm{X}$ linked mental retardation. However, the advent of a molecular test for the condition showed that its prevalence was significantly overestimated ${ }^{30}$ and highlighted inadequacies in the use of apparently diagnostic clinical features. ${ }^{31}$ These findings have implications for the interpretation of studies estimating the proportion of mental retardation owing to $\mathrm{X}$ linked genes, the proportion of $\mathrm{X}$ linked mental retardation resulting from the fragile $\mathrm{X}$ syndrome, and the recurrence risks for mental retardation where subjects with a putative diagnosis of fragile $\mathrm{X}$ syndrome were defined. For example, Morton et $a l^{8}$ have restudied children from a population survey originally diagnosed with fragile $\mathrm{X}$ syndrome. They show that in 18 out of 29 cases the original diagnosis was incorrect.
NON-SPECIFIC, X LINKED MENTAL RETARDATION The difficulty in testing Lehrke's hypothesis through direct measurement of the population frequency of $\mathrm{X}$ linked mental retardation is that it is not possible reliably to distinguish this type of mental retardation from that resulting from other causes, genetic or otherwise, just as it is often difficult to distinguish between forms of mental retardation which definitely have an $\mathrm{X}$ linked pedigree pattern. In the latter situation, however, an approach to differentiation can be made through detailed phenotype analysis and localisation of the causal gene in appropriate families. $^{32}$ At present, only 10 to 12 nonoverlapping loci are required to explain all localisations of non-specific $\mathrm{X}$ linked mental retardation so far identified. ${ }^{33}$ Much research is directed towards identifying $\mathrm{X}$ linked genes, but is this activity assisting the clinical geneticist at present? In our experience, the response is, "not greatly". Among the expanding number of published $\mathrm{X}$ linked mental retardation syndromes, there is such considerable overlap of supposedly distinctive phenotypic features (for example, obesity, macrocephaly, mild microcephaly, hypotonia, hypogonadism) that confident clinical diagnosis and genetic counselling advice is impossible given the commonest presenting scenario, the isolated affected male, or even when affected brothers present. In this situation we revert to empirical advice and published data on nonspecific mental retardation.

\section{Recurrence risks}

COMPARABLE SURVEYS?

Despite the commonplace nature of the clinical problem, a search of published reports identifies surprisingly few studies of recurrence risks in mental retardation. A table of key papers is given above (table 1). A number of points arise. Firstly, most of these papers are over 10 years old. Improvements in diagnostic technology result in a "chipping away" of cases which would previously have been labelled as idiopathic in nature and this point is particularly important where cytogenetic analysis was not part of the patient's assessment. Moreover, none of these papers was published after the introduction of a molecular test for fragile $\mathrm{X}$ syndrome. Secondly, differences in the populations studied produce problems specific to the method chosen and thus studies are 
Table 4 Sib recurrence risks in non-specific mental retardation

\begin{tabular}{|c|c|c|}
\hline Reference & Recurrence risk & Comments \\
\hline 27 & $10 \%$ & $\begin{array}{l}\text { Subset of } 43 \text { children with severe mental retardation. Risk is } \\
\text { for mild and severe mental retardation }\end{array}$ \\
\hline 35 & $19 \%$ & $\begin{array}{l}45 \text { cases (table } 2 \text { ). Not analysed by degree of mental } \\
\text { retardation }\end{array}$ \\
\hline 15 & $14 \%$ & $\begin{array}{l}40 \text { cases with "pure", severe mental retardation without } \\
\text { autism }\end{array}$ \\
\hline
\end{tabular}

difficult to compare. Although whole population studies are larger and less subject to bias than clinic or hospital based series (with an inherent tendency to selection of more severe or unusual cases and families where there has already been a recurrence), the criteria for inclusion of cases are unlikely to be verified by the reporting investigators. Also, although preferable from the epidemiological perspective, population based studies are probably less useful to the geneticist because clinic based series more resemble the selected population referred to the genetic clinic. Thirdly, previous categorisation of mental retardation by subgroups varies widely and makes it difficult to compare results. Of particular note are inconsistencies in the assignment of perinatal events as a cause of mental retardation. It is important that cases are not removed from study with a diagnosis of "cerebral palsy" when the evidence for this is insubstantial. Nowadays, clinical and neuroimaging evidence of prenatal and perinatal hypoxicischaemic damage is rigorously assessed in each case (the "joint" paediatric neurologygenetic clinic is invaluable for this purpose), but it is difficult to imagine that older genetic studies of mental retardation did not misclassify a significant proportion of cases. Given the above reservations, it becomes understandable that the recurrence risk results summarised in tables 2 and 3 do vary so much.

\section{MILD MENTAL RETARDATION}

The high recurrence risks given for mild mental retardation are especially notable. The data of Bundey et $a \bar{t}$ and Costeff and Weller ${ }^{29}$ are likely to be derived from families who have other relatives, including one or both parents, with an IQ at the lower end of the normal range. These families often have considerable socioeconomic disadvantages, thus bringing environmental influences into the equation. In our experience of holding genetic clinics at community based child development centres, the affected children in these families are physically well and their parents do not actively seek genetic advice. Rather, they tend to be referred for genetic-diagnostic assessment by community child health workers who now appreciate the significance of genetic diagnoses such as fragile $\mathrm{X}$ syndrome in this group. It may be that these high recurrence risk figures do not apply to the majority of cases seen routinely for genetic assessment and, as Bundey $e t a P$ suggest, where there is an obvious difference in intelligence between parents and child, a lower recurrence risk may be appropriate.
NON-SPECIFIC MENTAL RETARDATION

The studies reviewed above mostly relate to all forms of idiopathic mental retardation, whereas we suspect the recurrence risk is higher in cases of non-specific mental retardation, that is, the well grown, non-dysmorphic, usually male, child who has no clinical problems other than moderate or severe mental handicap (table 4). It is very likely that many of these cases result from single gene defects, rather than environmental or chromosomal causes, although the relative proportions of autosomal and $\mathrm{X}$ linked genes are unknown. $^{36}$

\section{RISKS FOR SISTERS' SONS}

The risks for sisters' sons depend mainly upon the risk of a mentally retarded male having an $\mathrm{X}$ linked condition. There are no available empirical data to answer this question. It is possible to derive risks ${ }^{37}$ using figures from Herbst and Miller's study ${ }^{25}$ of mental retardation in British Columbia. As discussed above, these calculations are based on a number of assumptions which are unproven.

\section{Conclusions}

We set out to review studies of recurrence risks in mental retardation already knowing that data for genetic counselling are limited and difficult to extract. Significant differences exist between studies and these are reflected in the figures given in medical genetics textbooks. ${ }^{37} 38$ Moreover, a recent postal survey of Consultant Clinical Geneticists in the UK suggests that clinicians vary in their assessment of recurrence risks, the importance of $\mathrm{X}$ linked genes, and the significance of dysmorphism for recurrence risks (appendix 1). Although advances in diagnostic techniques and the gene mapping of syndromes associated with mental retardation mean that idiopathic mental retardation is a dynamic concept, it is likely that we will remain dependent on empirical data for the foreseeable future when asked about the isolated case with unexplained mental retardation. We suggest that further empirical studies are needed and are as challenging as exercises in gene localisation. Future studies will incorporate detailed clinical evaluation of cases, molecular testing for the fragile $\mathrm{X}$ syndrome, and, ideally, a molecular cytogenetic test for cryptic chromosomal rearrangements. In this way it should be possible to derive accurate and comparable risk figures which can be used in counselling affected subjects and their families.

We would like to thank the anonymous reviewers of the initial submission for their helpful comments.

1 Penrose LS. A clinical and genetic study of 1,280 cases of mental defect. Medical Research Council Special Report Series 1938:229.

2 Reid AH. Mental handicap or learning disability. A critique of political correctness. Br $\mathcal{F}$ Psychiatry 1997;170:1.

3 World Health Organiztion. Nature of the problem. Mental retardation: meeting the challenge. WHO Offset Publication
(W.

4 Lamont MA, Dennis NR. Aetiology of mild mental retardation. Arch Dis Child 1988;63:1032-8.

5 Bundey S, Thake A, Todd J. The recurrence risks for mild idiopathic mental retardation. F Med Genet 1989;26:260-6. 6 Bundey S, Webb TP, Thake A, Todd J. A community study of severe mental retardation in the West Midlands and the importance of the fragile $X$ chromosome in its aetiology. $f$ Med Genet 1985;22:258-66. 
7 Roeleveld N, Zielhuis GA, Gabreëls F. The prevalence of mental retardation: a critical review of recent literature. Dev Med Child Neurol 1997;39:125-32.

8 Penrose LS. The biology of mental defect. 3rd ed. London: Sidgwick and Jackson, 1963.

9 Siminoff E, Bolton P, Rutter M. Mental retardation: genetic findings, clinical implications and research agenda. $\mathcal{f}$ Child findings, clinical implications and rese
Psychol Psychiatry 1996;37:259-80.

10 Richardson S, Koller H. Epidemiology. In: Clarke AM, Clarke ADB, Berg JM, eds. Mental deficiency: the changing outlook. 4th ed. London: Methuen, 1985.

11 Broman S, Nichols PL, Shaughnessy P, Kennedy W. Retardation in young children: a developmental study of cognitive deficit. Hillsdale, NJ: Lawrence Erlbaum, 1987.

12 Yeargin-Allsopp $M$, Murphy CC, Cordero JF, Decouflé $P$ Hollowell JG. Reported biomedical causes and associated medical conditions for mental retardation among 10-year old children, metropolitan Atlanta, 1985 to 1987 . Dev Med Child Neurol 1997;39:142-9.

13 Mitchell S, Bundey S. Symmetry of neurological signs in Pakistani patients with probable inherited spastic cerebral palsy. Clin Genet 1997;51:7-14.

14 Pilz DT, Quarrell OWJ. Syndromes with lissencephaly. $f$ Med Genet 1996;33:319-23.

15 Opitz JM, Kaveggia EG, Durkin-Stamm MV, Pendleton E. Diagnostic/genetic studies in severe mental retardation. Birth Defects 1978;XIV(6B):1-38.

16 Majnemer A, Shevell MI. Diagnostic yield of the neurologic assessment of the developmentally delayed child. $\mathcal{F}$ Pediat 1995;127:193-9.

17 Flint J, Yule W. Behavioural phenotypes. In: Rutter M, Taylor E, Hersov L, eds. Child and adolescent psychiatry. 3rd ed. Oxford: Blackwell Scientific Publications, 1994:666-87.

18 Tolmie JLT. Neural tube defects and other congenital malformations of the central nervous system. In: Rimoin DL, Connor JM, Pyeritz RE, eds. Emery and Rimoin's principles and practice of medical genetics. 3rd ed. New York
Churchill Livingstone, 1997:2145-76.

19 Smalley SL, Asarnow RF, Spence MA. Autism and genetics: a decade of research. Arch Gen Psychiatry 1988;45:953-61.

20 Flint J, Wilkie AOM, Buckle VJ, Winter RM, Holland AJ, McDermid HE. The detection of subtelomeric chromo-
somal rearrangements in idiopathic mental retardation. Nat Gemet 1995;9:132-40.

21 Ledbetter DH. Minireview: cryptic translocations and telomere integrity. Am f Hum Genet 1992;51:451-6.

22 Turner G, Turner B. X linked mental retardation. $f$ Med Genet 1974;11:109-13.

23 Lehrke RG. X-linked mental retardation and verbal disability. Birth Defects 1974; X(1):1-97.

24 Herbst DS, Baird PA. Sib risks for nonspecific mental retardation in British Columbia. Am ₹ Med Genet 1982;13:197 208.

25 Herbst DS, Miller JR. Nonspecific X-linked mental retardation. II. The frequency in British Columbia. $\mathrm{Am} \mathrm{f} \mathrm{Med}$ Genet 1980;7:461-9.

26 Morton NE, Rao DC, Lang-Brown H, MacLean CJ, Bart RC, Lew R. Colchester revisited: a genetic study of mental RC, Lew R. Colchester revisited: a
defect. $\mathcal{F}$ Med Genet 1977;14:1-9.

27 Bundey S, Carter CO. Recurrence risks in severe undiagnosed mental deficiency. $\mathfrak{F}$ Ment Defic Res 1974;18: 115-34.

28 Morton JE, Bundey S, Webb TP, MacDonald F, Rindl PM Bullock S. Fragile $\mathbf{X}$ syndrome is less common than previously estimated. $₹$ Med Genet 1997;34:1-5.

29 Costeff $\mathrm{H}$, Weller $\mathrm{L}$. The risk of having a second retarded child. Am ₹ Med Genet 1987;27:753-66.

30 Turner G, Webb T, Wake S, Robinson H. Prevalence of fragile X syndrome. Am $\mathcal{F}$ Med Genet 1996;64:196-7.

31 Slaney SF, Wilkie AOM, Hirst MC, et al. DNA testing for fragile X syndrome in schools for learning difficulties. Arch Dis Child 1995;72:33-7.

32 Stevenson RE, Häne B, Fernando Arena J, et al. Arch fingerprints, hypotonia and areflexia associated with $\mathrm{X}$ fingerprints, hypotonia and areflexia associated with

33 Lubs HA, Chiurazzi P, Fernando Arena J, Schwartz C Tranebjaerg L, Neri G. XLMR genes: update 1996. Am $\mathscr{f}$ Med Genet 1996;64:147-57.

34 Turner G, Collins E, Turner B. Recurrence risk of mental retardation in sibs. Med $\mathcal{F}$ Aust 1971;1:1165-7.

35 Bartley JA, Hall BD. Mental retardation and multiple congenital anomalies of unknown etiology: frequency of occurrence in similarly affected sibs of the proband. Birth Defects 1978;XIV(6B):127-37.

36 Young ID, Nugent Z, Grimm T. Autosomal recessive or sex linked recessive: a counselling dilemma. $\mathcal{F}$ Med Genet 1986 23:32-4.

37 Bundey S. Abnormal mental development. In: Rimoin DL, Connor JM, Pyeritz RE, eds. Emery and Rimoin's principles and practice of medical genetics. 3rd ed. New York: Churchill Livingstone, 1997:725-36.

38 Harper PS. Practical genetic counselling. 4th ed. Oxford: Butterworth-Heinemann, 1993.

39 Ghaffari SR, Boyd E, Tolmie JL, Crow YJ, Trainer AH, Connor JM. A new strategy for cryptic telomeric translocation screening in patients with idiopathic mental retardation screening in patients with idiop
tion. $₹$ Med Genet 1998;35:225-33.
Appendix 1

Questionnaires were sent to 70 Consultant Clinical Geneticists throughout the UK. Replies were received from 46; four did not include specific risk figures leaving 42 to be analysed. Clinicians were asked to suggest a recurrence risk in the following scenarios. It was stated that the children had been assessed by a paediatric neurologist and a clinical geneticist and that investigations, including molecular testing for FRAX and chromosome analysis, were normal.

(1) The proband is a male aged 8 years. The pregnancy and perinatal period were uneventful. He walked at 13 months. He was referred to a paediatrician at 2 years 8 months because of poor speech development. He has problems with the understanding and use of language but manages at standard school with help from a specialist teacher for children with special needs. A recent IQ assessment was given as 65 . Apart from a degree of clumsiness, motor function is normal. He has no dysmorphic features. There is no family history of note. His intellectually normal parents both attended standard school.

(2) The proband is female. The clinical details are otherwise as in (1).

(3) The proband is a 3 year old male. The pregnancy and perinatal period were uneventful. Global developmental delay was obvious by age 14 months. There are no features of regression. He is now cruising but is still unable to walk independently. He has no words. Investigation including CT neuroimaging have failed to show a cause for his severe handicap. $\mathrm{He}$ has no dysmorphic features. There is no family history of note.

(4) The proband is female. The clinical details are otherwise as in (3).

(5) The proband is a male. Details are the same as in (3) except that the child has nonfamilial mild short stature, posteriorly rotated ears, epicanthic folds, clinodactyly, and an OFC at $-2.5 \mathrm{SD}$.

Results were analysed in the risk ranges below

\begin{tabular}{|c|c|c|}
\hline & Male index case & Female index case \\
\hline \multicolumn{3}{|l|}{ (1)\&(2) } \\
\hline $1-5 \%$ & 23 & 35 \\
\hline $6-10 \%$ & 13 & 1 \\
\hline $20-25 \%$ & 6 & 6 \\
\hline Total & 42 & 42 \\
\hline \multicolumn{3}{|c|}{$\begin{array}{l}26 \text { of } 42 \text { clinicians gave a higher recurrence risk if the index } \\
\text { case were male }\end{array}$} \\
\hline (3) $\&(4)$ & Male index case & Female index case \\
\hline $1-5 \%$ & 29 & 40 \\
\hline $6-10 \%$ & 13 & 2 \\
\hline Total & 42 & 42 \\
\hline \multicolumn{3}{|c|}{$\begin{array}{l}26 \text { of } 42 \text { clinicians gave a higher recurrence risk if the indes } \\
\text { case were male }\end{array}$} \\
\hline \multicolumn{3}{|c|}{$\begin{array}{l}\text { (3) } \&(5) \\
\text { If the index case was dysmorphic then: } \\
12 \text { Consultants left the risk unchanged } \\
12 \text { Consultants increased the risk } \\
18 \text { Consultants decreased the risk }\end{array}$} \\
\hline
\end{tabular}

